\title{
II CONGRESSO BRASILEIRO DE DIREITO ADMINISTRATVO
}

Do dia 23 a 28 de junho de 1976, terá lugar na cidade do Rio de Janeiro, sob o patrocínio da Fundação Getúlio Vargas, o II Congresso Brasileiro de Direito Administrativo.

Para organizar o segundo encontro de administrativistas brasileiros, ficou constituída a seguinte Comissão Executiva: Themistocles Brandão Cavalcanti, Carlos Medeiros Silva, Caio Tácito, Seabra Fagundes, Cotrim Neto, Sergio de André Fereira, Armando Marinho e Sergio Ferraz.

Instalará o conclave do Rio de Janeiro, como seu presidente, o professor Manoel de Oliveira Franco Sobrinho, catedrático da Universidade Federal do Paraná, e também na qualidade de presidente do Instituto Brasileiro de Direito Administrativo.

Temas propostos: a "Justiça Administrativa em face da Constiruição de 1969"; "Organização administrativa e serviço público"; "Problemas da Administração Indireta"; e o "Papel do Estado na ordem jurídico-administrativa". 